\title{
Passive revolution: A universal concept with geographical seats
}

\begin{abstract}
In this article, I argue that Antonio Gramsci's concept of passive revolution makes a foundational contribution to International Relations (IR), yet has been relatively under appreciated by the broader discipline. Within the Historical Sociology of International Relations, uneven and combined development has recently been postulated as a key trans-historical law that provides a social theory of the 'international'. Drawing from, but moving beyond these debates, I will argue that passive revolution is a key conditioning factor of capitalist modernity. I will demonstrate how the concept of passive revolution is the element that explains the connection between the universal process of uneven development and the manner in which specific combinations occur within the capitalist era as geopolitical pressures, in tandem with domestic social forces become internalised into geographically specific state forms. It therefore offers a corrective to the frequently aspatial view that is found in much of the literature in IR regarding uneven and combined development. Additionally, passive revolution provides a more politicised understanding of the present as well as an important theoretical lesson in relation to what needs to be done to affect alternative trajectories of development.
\end{abstract}

\section{Key words}

Gramsci, passive revolution, uneven development, capitalism, revolution 


\section{Introduction}

The title of this article takes its cue from a remark by Antonio Gramsci in the Prison Notebooks regarding what he calls 'universal concepts with geographical seats'. In the context of his writing, Gramsci is discussing Italy and its lack of a fully developed national culture. Instead, he reflected, the peninsula was influenced by the cosmopolitanism of a small elite who remained detached from the masses. ${ }^{2}$ In this article, I utilise both the generalised method of examining a social formation within the broader global context of which it is both constitutive and constituted by, but also the specific class basis for the national developmental projects of countries. I draw attention to how - throughout modernity - passive revolution has been a persistent and universal feature of developmental change. However, the way it manifests itself and unfolds has differed depending on the particular country or region involved. It is a process, therefore, that has been structurally conditioned by the broader global political economy, yet contingently articulated in various contexts giving the term its geographical seats.

Fred Halliday once opined that the study of revolution had been neglected within International Relations. He proposed that any such future enquiry should comprise the following three areas: 1) locating the place of revolutions and explaining their influence on the international system more broadly, 2) exploring the international dimensions of any revolution and 3) reflecting on what theoretical issues the study of revolutions pose. ${ }^{3}$ In this article I will contend that Gramsci's concept of passive revolution allows us to do all of these tasks. Namely, it informs us of the dialectic relationship between national (and subnational) state formation and the international context (and subsequent ramifications that change brings). It also allows us to draw theoretical lessons from this with regards to a political strategy for emancipation by learning from history. In contrast to those who

\footnotetext{
${ }^{1}$ Antonio Gramsci, Selections from the Prison Notebooks, translated and edited by Quentin Hoare and Graham Nowell-Smith (London: Lawrence and Wishart, 1971), p.117, Q10II§61. I have followed the international standard for referring to Gramsci's work using the notebook (Q) as well as the note number (§). The concordance table for this can be found of the International Gramsci Society website http://www.internationalgramscisociety.org

${ }^{2}$ Peter Ives and Nicola Short, 'On Gramsci and the international: a textual analysis', Review of International Studies, 39: 3 (2013), p.638.

${ }^{3}$ Fred Halliday, Rethinking International Relations (Basingstoke: Macmillan, 1994), pp.127-8.
} 
have sought to dismiss Gramsci as a theorist only of national politics, ${ }^{4}$ this article therefore adds weight to the claim that Gramsci offers a foundational contribution to the study of international relations. ${ }^{5}$ The concept of passive revolution, moreover, is stressed to be a key complement to the notion of uneven and combined development (U\&CD) that has recently gained purchase as an analytical category within the Historical Sociology of International Relations (HSIR). It will be argued that passive revolution helps to enhance and give wider political resonance to this latter concept, explaining the connection between wider processes of uneven development and the specific manner in which combination occurs during the capitalist epoch, as geo-political pressures generated from this mode of production, in tandem with domestic social forces, become internalised into geographically specific state forms. Stated more concretely, passive revolution puts class struggle and preoccupations with societal transformation (indeed revolution) back onto the political agenda. Such a focus on revolution was integral to the original formation of U\&CD by Leon Trotsky (as will be discussed later), but has been largely absent from the concern of scholars associated with the latest wave of scholarship on the topic. Thus, whereas current trends in U\&CD can collapse into a detached structural commentary via the positing of trans-historical laws (from which there can appear little escape), passive revolution breaks with this. It does so by offering more modest claims, namely to explore the specific expression of U\&CD within the capitalist epoch. Through the definite geographical seats by which the concept is rendered and operationalised, passive revolution focuses much greater attention on actual processes of class struggle and state formation, grounding the places and spaces of revolutions sociologically. ${ }^{6}$ This obviously does include the stratagems of ruling classes that disaggregate and domesticate subaltern class struggles. However, this is analysed to the extent that intellectual efforts can be used to inform a philosophy of praxis that is anti-passive revolutionary

\footnotetext{
${ }^{4}$ Randall D. Germain and Michael Kenny, 'Engaging Gramsci: International Relations Theory and the New Gramscians', Review of International Studies, 24:1 (1998), pp. 3-21; Julian Saurin 'The Formation of NeoGramscians in International Relations and International Political Economy: Neither Gramsci nor Marx' in Alison J Ayers, (ed) Gramsci, Political Economy, and International Relations Theory: Modern Princes and Naked Emperors (New York: Palgrave, 2008).

${ }^{5}$ Robert Cox, 'Gramsci, Hegemony and International Relations: An Essay in Method', Millennium: Journal of International Studies, 12:2 (1983), pp.162-175; Ives and Short (2013); Adam D. Morton, ': State Formation, Passive Revolution and the international', Millennium: Journal of International Studies, 35:3 (2007), pp. 597621.

${ }^{6}$ Adam D Morton, 'The Continuum of Passive Revolution', Capital \& Class, 34: 3 (2010), p321.
} 
in its orientation. Ultimately this needs to be done by moving debates away from a narrow circle of professional intellectuals to become an element of culture. ${ }^{7}$

It has already been recognised that $\mathrm{U} \& \mathrm{CD}$ provides a bridge to wider social theory, including Gramscian thought. ${ }^{8}$ More decisively, Michael Burawoy once suggestively stated that 'Where Trotsky's horizons stop, Gramsci's begin'. ${ }^{9}$ Building on this statement, it will be argued that the two thinkers' key ideas (uneven and combined development for Trotsky and passive revolution for Gramsci) demonstrate a complementarity with one another, that, when taken together, are integral to explaining the core features of international relations under capitalism. ${ }^{10}$ Used in tandem they can provide a powerful statement for historical materialism's foundational contribution to the discipline of International Relations.

Before proceeding it is important to clarify some important meanings at this stage. To be clear, in claiming that passive revolution is a universal concept I am decidedly not saying that it is transhistorical in nature (as is the claim by some scholars regarding U\&CD). As will be explained in more detail later, passive revolution is only capable of referring to the capitalist era. Rather, in invoking the term 'universal' I am implying that the term is equally applicable throughout the world. Furthermore, it should be noted that the phrase employed in this article 'capitalist modernity' is not without controversy. Ellen Meiksins Wood for example, has forcefully argued for these two terms not to be conflated as their meanings are not identical. ${ }^{11}$ However, whilst one may not necessarily disagree with such a proposition, the claim here, following Burns, is that whilst the two terms are not historically

\footnotetext{
${ }^{7}$ Antonio Gramsci, Prison Notebooks Vol.2 (ed. Joseph Buttigieg) (New York: Columbia University Press, 2011b), p233, Q4§60. One such effort to make the concept become a part of popular culture has come from Enrique Semo, interviewed in Mexican national newspaper La Jornada, see Ericka Montaña Garfias, 'México vive una una revolución pasiva, asegura Enrique Semo', La Jornada (23 November 2014).

8 John Hobson, 'What is at Stake in the Neo-Trostkyist Debate? Towards a Non-Eurocentric Historical Sociology of Uneven and Combined Development', Millennium: Journal of International Studies, 40:1 (2011), p.141.

${ }_{9}^{9}$ Michael Burawoy, 'Two methods in search of science' Theory and Society, $18: 6$ (1989), p. 793. I am indebted to Adam D Morton for drawing my attention to this quote.

${ }^{10}$ See also, Adam D Morton, Revolution and the State in Modern Mexico: The Political Economy of Uneven Development (Plymouth: Rowman and Littlefield, 2011), p.4

${ }^{11}$ Ellen Meiksins Wood, 'Modernity, postmodernity or capitalism?' Review of International Political Economy, $4: 3$ (2007), pp.539-560.
} 
necessary to one another, they have been contingently related in reality and this requires explanation. ${ }^{12}$ Passive revolution therefore offers a theory of modernity that illuminates why capitalism has remained hegemonic in this epoch. ${ }^{13}$

Prior to embarking on this intellectual endeavour, it should be noted that a host of preliminary objections need to be overcome. These objections link to 1) the suitability of having 'universal' concepts, 2) the related issue of whether the construction of universal arguments leads to a Eurocentric diffusionist viewpoint that denies other people(s) and places their own agency in the making of history, and, 3) there is the objection that such an argument leads to the problem of 'concept stretching'. Let us deal with each objection in turn.

Regarding the issue of universal concepts, such a notion has clearly experienced sustained attack from postmodernism. Reduced to its most basic propositions, postmodernism claims that no singular historical narrative exists and that furthermore, there is always a diversity of meaning and identities which problematise any easy comparison between traditional categories in the social sciences. ${ }^{14}$ This epistemology has gained wider purchase in IR through the distinct, but related body of thought, postcolonialism. ${ }^{15}$ This article is, by contrast, unashamedly trying to construct a meta-narrative of modernity, and indeed would make the case that the haste to discard any grand narrative is in fact misguided. Here the incredulity expressed by postmodernism towards grand theory can easily slip into myopia by its failure to see interconnections and the unfolding of distinct logics at work. ${ }^{16}$ In defence of such a proposition, two key arguments can be marshalled. First, general abstractions are in fact

\footnotetext{
${ }^{12}$ Tony Burns, 'Capitalism, modernity and the nation state: A critique of Hannes Lacher', Capital \& Class, 34 : 2, pp. 246, 250.

${ }^{13}$ Peter Thomas, The Gramscian Moment: Philosophy, Hegemony and Marxism (London: Brill, 2009), pp.1557.

${ }^{14}$ Halliday, Rethinking International Relations, p.38; Jean-François Lyotard, The Postmodern Condition: A Report on Knowledge (Manchester: Manchester University Press, 1984).

${ }^{15}$ Alex Callinicos, Imperialism and Global Political Economy (Cambridge: Polity. 2009), p.6; Kamran Matin, 'Redeeming the universal: Postcolonialism and the inner life of Eurocentrism', European Journal of International Relations, 19:2 (2013), pp. 353-377.

${ }^{16}$ Ferderic Jameson, Postmodernism, or, The Cultural logic of Late Capitalism (London: Duke University Press). Drawing from Ludwig Wittgenstein, Lyotard, 1984, invoked language games to demonstrate how different social situations acquire their own rules and intelligibility that are not transferable to other situations. However, this is to ignore the fact that we still require the over-arching knowledge of what a language game is to understand such micro-situations.
} 
necessary to be able to make any kind of meaningful comparative historical analysis. It is possible, therefore, to think of key elements of the social world that, whilst differing in time and space, still fundamentally constitute social reality. ${ }^{17}$ The issue at stake here is how one thinks of such categories of identity. As Rosenberg explains with regards to Trotsky's philosophical premises on this matter:

Trotsky points out that no two cone bearings in a production batch will ever be exactly identical; but so long as their variation remains within a given margin of 'tolerance', they may safely be treated as if they were so. And something similar, he suggests, applies to concepts: they too have a margin of tolerance, within which their non-correspondence to their objects can in practice be disregarded. ${ }^{18}$

Second, I do not discount the importance of localised experience and specificity that numerous postmodern and post-structuralist scholars have sought to draw our attention to. ${ }^{19}$ Rather, the article highlights how particularity remains within a universal framework. This is the reason why seemingly discrepant phenomenon such as Keynesianism and Fascism can both be interpreted within the broader logic of passive revolution, (as will be further detailed later). In each case the form is the same but the local content (the geographical seats) differ. Thus, as Gramsci declared, 'Finding the real identity underneath the apparent differentiation and contradiction and finding the substantial diversity underneath the apparent identity is the most essential quality of the critic of ideas and of the historian of social development. ${ }^{20}$

The meaning implied by the term 'universal' clearly does matter however, which links closely with the potential objection of Eurocentrism. Eurocentrism is defined by the belief in the primacy of European development that is sui generis. Such a view downplays or ignores wider interconnections (including those of slavery and imperialism), whilst holding the European pattern of development as

\footnotetext{
17 Justin Rosenberg, 'Kenneth Waltz and Leon Trotsky: Anarchy in the mirror of uneven and combined development', International Politics, 50:2 (2013a), p.194.

18 Justin Rosenberg, 'The philosophical premises of uneven and combined development', Review of International Studies, 39:03 (2013b), p.575.

${ }^{19}$ Lyotard, The Postmodern Condition; Michel Foucault, Power/Knowledge: Selected interviews and other writing 1972-77, edited by Colin Gordon, (New York: Pantheon Books, 1980).

${ }^{20}$ Antonio Gramsci, Prison Notebooks Vol.1 ed. Joseph Buttigieg, (New York: Columbia University Press, 2011), p. 128-9, Q1§43.
} 
the superior standard to which other countries must inevitably aspire and be measured by. ${ }^{21} \mathrm{~A}$ potential danger in the argument constructed here could be that the notion of passive revolution succumbs to a diffusionist reading of history that sees European capitalism transforming the world (unproblematically) in its own image, with social forces in other regions and states lacking any agency in this process. ${ }^{22}$ Such an understanding, however, would be insufficiently dialectical on two separate counts. First, there is no need to assume that any form of development, including that of capitalism, takes place in national isolation. ${ }^{23}$ Indeed, this was contrary to Gramsci's formulation of the concept of passive revolution as will be detailed below. In this sense, passive revolution can be read as a method of incorporated comparison as it seeks to show the interconnections between social phenomena across time and space. ${ }^{24}$ The method of incorporated comparison takes neither the whole (world system), nor its constituent parts (regions, countries etc) as fixed units of analysis. Instead, this method is attentive to the dialectic relation between them, and does not claim either as the prime locus of explanation. In McMichael's words, the incorporated comparative method 'progressively constructs the whole as a methodological procedure by giving context to historical phenomenon. ${ }^{25}$ The stress is on the cumulative process of history. Comparison therefore, 'is 'internal' to historical inquiry, whereby process instances are comparable because they are historically connected and mutually conditioning, ${ }^{26}$ This approach has the advantage of allowing us to appreciate the totality of capitalist relations (and the geopolitical pressures that it thereby generates) whilst being attentive to its different articulations at various spatial scales. Second, a diffusionist reading should be rejected owing to the stress that Gramsci put on the inevitability of resistance to the process of passive

\footnotetext{
${ }^{21}$ Matin, 'Redeeming the universal', p.354; Robbie Shilliam, 'The Atlantic as a vector of uneven and combined development', Cambridge Review of International Affairs, 22:1 (2009, pp. 69-88; Cemal Burak Tansel, 'Deafening silence? Marxism, international historical sociology and the spectre of Eurocentrism', European Journal of International Relations, 21:1 (2015), p.78.

${ }^{22}$ Adam D Morton, Unravelling Gramsci: Hegemony and Passive Revolution in the Global Political Economy, (London: Pluto Press, 2007), pp. 49-50.

${ }^{23}$ John Hobson, The Eastern origins of Western civilisation (Cambridge: Cambridge University Press, 2004).

${ }^{24}$ Phillip McMichael, 'Incorporating comparison within a world-historical perspective: An alternative comparative method', American Sociological Review, 55:3 (1990), pp.385-397; Morton, 'Waiting for Gramsci', p.618

${ }^{25}$ Ibid p.386.

${ }^{26}$ Phillip McMichael, 'World-Systems Analysis, Globalization and Incorporated Comparison', Journal of World Systems Research, 3 (2000), p.671. This partially serves as an answer to Hobson's, 2011, question about what is added in discussions of the international in these new debates that cannot be provided by previous World System's analysis (as the latter do indeed take countries and regions as fixed units of analysis as well as the world system itself).
} 
revolution. This rejects any simple notion of unproblematic and unilinear development. Rather than a one-way transmission of power and ideas, it is better to think of passive revolution as emanating from what Gramsci referred to as centres 'of formation, of irradiation, of dissemination. ${ }^{27}$

Kamran Matin has usefully pointed out the contradiction between theory and method in postcolonial thought. On the one hand, it rejects the universalism or macro-historical explanation that is associated with Eurocentrism, yet on the other hand it relies on a method of understanding colonial societies as being forged through their inter-societal constitution. However, he argues that,

A unified theoretical comprehension of the social and the international must...be central to any attempt at supplanting Eurocentrism. This requires an explicit theoretical incorporation of the universal. But a conception of the universal that is fundamentally rethought away from being an immanent self-transcendence of the particular. ${ }^{28}$

Passive revolution I believe is capable of such a form of universalism that maintains a focus on the cumulative process of shared history, but retains a focus on national particularity. To sum up, quoting from Gramsci, 'the premise of an "organic diffusion from a homogenous centre and a homogenous way of thinking and acting" is not sufficient. The same ray of light passes through different prisms and yields different refractions of light. ${ }^{29}$

The final objection relates to the issue of concept stretching. This refers to the wider usage of a term beyond which it was originally intended, so as to rob it of its meaning and explanatory power. Such a scepticism towards the wider usage of passive revolution has been raised by Alex Callinicos who is wary of the concept "just becoming another way of referring to the dynamism and flexibility of capitalism. ${ }^{30}$ Just as Neil Smith criticised the indiscriminate use of the term 'uneven development', there is the danger that passive revolution comes to explain everything, and therefore nothing. ${ }^{31} \mathrm{I}$

\footnotetext{
${ }^{27}$ Gramsci, Selections from the Prison Notebooks, p. 192, Q1§30.

${ }^{28}$ Matin, 'Redeeming the universal' p.355

${ }^{29}$ Gramsci, Prison Notebooks Vol.1, p.128, Q1§43

${ }^{30}$ Alex Callinicos, The Limits of Passive Revolution. Capital and Class, 34:3 (2010), p. 505.

${ }^{31}$ Neil Smith, 'The Geography of Uneven Development' in Bill Dunn and Hugo Radice (eds) 100 Years of Permanent Revolution (London: Pluto, 2006), p.182.
} 
contend, however, that this criticism can quite easily be overcome. Of course, the term passive revolution is trying to tell us something fundamental - and thus generalisable - about capitalism and international relations. However, it also points us towards a political strategy, namely the critique of the state and the need to move beyond this form of organising social relations. As Anne Showstack Sassoon argues with regards to this, passive revolution functions on two different levels, 'as a discussion of some historical events and as an expression of a theoretical problem. ${ }^{32}$ It is thus an inherently engaged and politicised concept that calls for reflection and alternatives as opposed to a detached form of academic commentary which some forms of U\&CD analysis fall into.

With these potential objections overcome, the argument for understanding passive revolution as a universal concept with geographical seats will now be made in the following manner. First, I will set out the main claims and achievements of IR scholars associated with the concept of U\&CD, before exploring some of the key criticisms that have been levelled against this school of thought. These include its ability to say something specific about capitalism, its shift away from being a concept designed to evaluate revolutionary possibilities and its aspatial nature. Second, I will outline the scope of passive revolution and, drawing examples from Gramsci and beyond, make the case for its universal applicability and various geographical seats. Finally, I conclude with a discussion of what passive revolution brings to such extant debates, demonstrating how the criticisms of U\&CD can be overcome when deployed in tandem with passive revolution. Taken together as mutually reinforcing concepts they demonstrate a powerful contribution that historical materialism can make to the discipline of International Relations.

${ }^{32}$ Anne Showstack Sassoon, Gramsci’s Politics (London: Croom Helm, 1980), p.205. 


\section{The contribution of uneven and combined development}

Over the last decade or so, U\&CD has contributed to a major new research agenda, pioneering a third wave of scholarship within the Historical Sociology of International Relations. ${ }^{33}$ Drawing from Leon Trotsky's original development of the concept, Justin Rosenberg has sought to further advance the term by claiming that $U \& C D$ offers not just a universal, but furthermore, a trans-historical concept of what development actually is. ${ }^{34}$ Whilst scholars have operationalised the term in different ways, the array of literature on this topic is a testament to its powerful explanatory power on a diverse range of issues, including inter alia the state-system and geopolitics, ${ }^{35}$ the origins of the First World War, ${ }^{36}$ state-formation ${ }^{37}$ and the possibilities of resistance in a transnational age. ${ }^{38}$

What then are its principle achievements? First, U\&CD offers a major statement about the causal importance of the 'international' in human history and development. ${ }^{39}$ In this explanation, the international, 'is marked by an inherent dynamism as more developed societies interact with less developed ones, causing combined development in backward societies, which reinforce rather than

\footnotetext{
${ }^{33}$ Hobson, 'What is at Stake'.

${ }^{34}$ Leon Trotsky, The Permanent Revolution and Results and Prospects (London: New Park, 1962); Leon Trotsky, The History of the Russian Revolution (London: Pluto Press, 1985; Justin Rosenberg 'Why is there no international historical sociology?', European Journal of International Relations, 12:3 (2006), pp.307-340; Justin Rosenberg, 'Basic problems in the theory of uneven and combined development: Part II unevenness and political multiplicity', Cambridge Review of International Affairs 23:1 (2010), pp.165-189; Rosenberg, 'Kenneth Waltz and Leon Trotsky'; Rosenberg, 'Philosophical premises'.

${ }^{35}$ Alex Callinicos, 'Does capitalism need the state system?', Cambridge Review of International Affairs, 20:4 (2007), pp. 533-549; Ray Kiely 'Spatial hierarchy and/or contemporary geopolitics: what can and can't uneven and combined development explain?', Cambridge Review of International Affairs, 25:2 (2013), pp.231-248; Hannes Lacher, Beyond Globalization: capitalism, territoriality and the international relations of modernity (London: Routledge, 2006); Benno Teschke, The Myth of 1648: Geopolitics, and the Making of Modern International Relations (London: Verso, 2003).

${ }^{36}$ Alexander Anievas, '1914 in world historical perspective: The 'uneven' and 'combined' origins of World War I', European Journal of International Relations, 19:4 (2013), pp.721-746; Jeremy Green, 'Uneven and combined development and the Anglo-German prelude to World War I', European Journal of International Relations, 18:2 (2012), pp.345-368; Rosenberg, 'Kenneth Waltz and Leon Trotsky'.

${ }^{37}$ Jamie Allinson, The Struggle for the State in Jordan: The Social Origins of Alliances in the Middle East (London: IB Tauris, 2015); Kamran Matin, 'Uneven and combined development in world history: the international relations of state-formation in premodern Iran', European Journal of International Relations, 13:3 (2007), pp. 419-447; Adam D Morton, 'Reflections on Uneven Development Mexican Revolution, Primitive Accumulation, Passive Revolution', Latin American Perspectives, 37:1 (2010), pp.7-34.

${ }^{38}$ Andreas Bieler, 'The EU, global Europe and processes of uneven and combined development: the problem of transnational labour solidarity', Review of International Studies, 39: 1 (2013), pp.161-183.

${ }^{39}$ Rosenberg, 'Basic problems'. International is defined here as the as the 'dimension of social reality which arises specifically from the coexistence within it of more than one society', Rosenberg, 'Why is there no international historical sociology?' p. 308.
} 
straighten out, the unevenness of world-historical development'. ${ }^{40}$ In contrast to the unilinear conception of development offered by modernization theory, U\&CD offers a multilinear and interactive framework whereby world history is presented as an ontological whole, therefore collapsing the false distinction between international and domestic society, and instead looking at the sociological constitution of difference. ${ }^{41}$ On this basis it becomes impossible to analyse a singular society without reference to its entanglement with others. This rules out methodological nationalism, and highlights how the so-called billiard ball imagery of societies - fully formed entities knocking into one another - can be rendered false. ${ }^{42}$

Second, U\&CD adds a greater dimension of sociological analysis to IR. It does so by providing a social theory of the 'international' which (it is alleged) has been neglected by hitherto existing theories, including those of a critical persuasion. ${ }^{43}$ Therefore, the concept is claimed to offer 'a much needed alternative conception of the historical process' ${ }^{44}$ In such a manner, U\&CD offers a profound challenge to the dominance of Realism and its ontological primacy of anarchy. It does so by dereifying this concept and instead demonstrating how it is an emergent property of uneven and combined development. In the place of anarchy as a foundational (yet unexplained) premise of international relations, it is argued that the conditioning situation of uneven and combined development serves to socialise state's behaviour. ${ }^{45}$

However, just as the concept has generated key research avenues it has also provoked intense debate. Some have argued that U\&CD scholars - most notably Justin Rosenberg - are themselves remiss in failing to explain the foundational premises of $U \& C D$ - namely what the primary causes of uneven

\footnotetext{
40 Benno Teschke, 'Advances and impasses in Fred Halliday's international historical sociology: a critical appraisal', International Affairs, 87:5(2011), pp.1087-1106.

${ }^{41}$ Rosenberg, 'Why is there no international historical sociology?' p. 327.

${ }^{42}$ Rosenberg, 'Philosophical premises', p.570; Eric Wolf, Europe and the People Without History (London: University of California Press, 1997).

${ }^{43}$ Rosenberg, 'Kenneth Waltz and Leon Trotsky', p.184; Rosenberg, 'Philosophical premises', p. 570.

${ }^{44}$ Alex Callinicos and Justin Rosenberg, 'Uneven and combined development: the social-relational substratum of 'the international'? An exchange of letters', Cambridge Review of International Affairs, 21:1 (2008), p. 85

${ }^{45}$ Hobson, 'What is at Stake'; Rosenberg (2010); Rosenberg, 'Kenneth Waltz and Leon Trotsky'.
} 
and combined development actually are, and how this changes during different epochs. ${ }^{46}$ Following a similar line of argument, Alex Callinicos, has stated that we need to retain an analysis based upon historically-specific modes of production if we are to cash-in the general abstraction that is uneven and combined development. ${ }^{47}$ This links to a much broader debate, namely the historical applicability of the term. For some, it is a concept that is only rendered meaningful within capitalist society and its particular dynamics. ${ }^{48}$ For others it has a more generalizable, indeed trans-historical validity. ${ }^{49}$ In many ways the disagreement in these debates link to the differing starting points of the respective authors. That is to say, they offer different explanations (explanans) owing to different explanandum (the phenomenon to be explained). For critics of the trans-historical position, it is claimed that this method of operationalising U\&CD risks turning a triviality or truism (that nothing develops evenly) into an historical law. It thereby transforms an axiom and a theorem into a theory. ${ }^{50}$ As Rioux has argued trenchantly regarding Rosenberg's propositions, 'his conceptualisation of U\&CD as a timeless structure of human development directly informs the poverty of his approach and its failure to move beyond descriptive generalisations. ${ }^{51}$ However, the prime motivation of Rosenberg's intellectual inquiry is to contribute to a historical materialist theorising of the 'international', specifically as the 'visualising and mapping of the international as a dimension of social causality.' ${ }^{52}$ His main explanandum therefore does not begin from a set of questions that seek to only understand the present conjuncture (e.g. whether multiplicity is or is not being transcended) ${ }^{53}$ Rather, it is the more abstract question of why we have multiplicity in the first place. In Rosenberg's words, therefore:

\footnotetext{
46 Kiely, 'Spatial hierarchy', p.237; Sébastien Rioux, 'Mind the (Theoretical) gap: On the poverty of international relations theorising of uneven and combined development', Global Society, 29:4 (2015), p.485.

${ }^{47}$ Callinicos and Rosenberg, 'Uneven and combined development', pp.82-3.

${ }^{48}$ Sam Ashman, 'Capitalism, uneven and combined development and the transhistoric, Cambridge Review of International Affairs, 22:1 (2009), pp. 29-46; Jamie Allinson and Alexander Anievas, 'The uses and misuses of uneven and combined development: an anatomy of a concept', Cambridge Review of International Affairs, 22:1 (2009), pp.47-67; Neil Davidson, 'Putting the nation back into 'the international', Cambridge Review of International Affairs, 22:1 (2009), pp. 9-28.

${ }^{49}$ Hobson, 'What is at Stake'; Matin 'Redeeming the Universal'; Rosenberg, 'Basic Problems', Rosenberg, 'Kenneth Waltz and Leon Trotsky'; Rosenberg 'Philosophical premises'.

${ }^{50}$ Kees van der Pijl, 'The Uneven and Combined Development of International Historical Sociology' in Radika Desai (ed), Theoretical Engagements in Geopolitical Economy Vol30a (Bingley: Emerald Group, 2015), pp. 60

${ }^{51}$ Rioux, 'Mind the (Theoretical) gap', p499.

${ }^{52}$ Rosenberg, 'Philosophical premises', p586.

${ }^{53}$ Van der Pijl, 'Uneven and Combined Development', p.47 takes issue with this mode of inquiry and claims that 'A Marxist critique must always relate to the present.'
} 
the point about 'unevenness' is not in the first instance that it posits inequalities and differences among coexisting societies; it is rather that, posited of social development, it makes sense of the existence of a plurality of societies in the first place - and with that, of the extension of a lateral field of interaction which is both intrinsic to and behaviourally distinct within the expanded conception of social development now posited. ${ }^{54}$

The concept is therefore mobilised for different modes of explanation, but the question arises whether such a conception is still able to usefully tell us about contemporary capitalism? It would seem that the more stock that is invested in making U\&CD a stronger general abstraction with trans-historical validity, the less it functions as a precise tool for analysing the specificity of capitalism (and how U\&CD develops under this mode of production). As Neil Smith put it, 'the potentially penetrating insights of the theory are dissolved when uneven development is seen as a universal metaphysics, its meaning reduced to the lowest common denominator. ${ }^{55}$ This is a lacuna that I believe passive revolution can fill and provides the case for why, to understand capitalist modernity, the two concepts must be used in tandem. Drawing from the work of Jairus Banaji we can say that conjoining the two concepts allows U\&CD to be transformed from a 'simple category' - a term common to multiple epochs - to a 'historically determinate category', or so called 'concrete category', integral to understanding a particular epoch. ${ }^{56}$ Passive revolution therefore gives the concept of U\&CD a greater degree of analytical clarity to understand the specificity of capitalist modernity.

What can more plausibly be asserted as a form of critique (and flows from the above argument), is that the social purpose of this mode of trans-historical inquiry does differ from that which the concept was originally intended. Ian Bruff has noted that the current literature on U\&CD is most comfortable when intellectual efforts are devoted to the study of pre-contemporary history (which marks its substantive field of research). ${ }^{57}$ This usage, whilst contributing to academic debates clearly does move

\footnotetext{
${ }^{54}$ Callinicos and Rosenberg, 'Uneven and combined development', p.94.

${ }^{55}$ Neil Smith, Uneven Development: Nature, capital and the Production of Space $3^{\text {rd }}$ edition, (London: Verso, 2010) p.135.

56 Jairus Banaji, Theory as History: Essays on Modes of Production and Exploitation (Chicago: Haymarket, 2011), p.54.

57 Ian Bruff, 'European varieties of capitalism and the international', European Journal of International Relations, 16:4 (2010a), pp. 615-638. For further evidence of this point, one can observe the concerns evident in the latest publication on U\&CD which remain overwhelmingly historical in nature, e.g. Alexander Anievas and Kerem Nişancioğlu, How the West Came to Rule (University of Chippenham: Pluto Press, 2015); Alexander Anievas and Kamran Matin, Historical Sociology and World History: Uneven and Combined Development over
} 
the concept away from Trotsky's original intention, namely to think about the possibilities for revolution. ${ }^{58}$ While Rosenberg believes this strengthens an historical materialist analysis of international relations, critics have argued that this has led to a shift from activism to academia that denudes a Marxist analysis of its core concepts of class formation and struggle. ${ }^{59}$ Contrariwise, it will be demonstrated below that such notions are intrinsic to the notion of passive revolution.

Finally, despite the fact that spatio-temporal claims are integral to the concept of $U \& C D,{ }^{60}$ much of the prominent literature fails to engage with the vast amount of geographical scholarship that has been produced on uneven development and instead narrowly focuses on a few scattered phrases of Trotsky. ${ }^{61}$ Space becomes an unexplored premise, a mere happenstance of developmental unevenness and combination. ${ }^{62}$ As a result, there is inadequate consideration of spatial questions and little spatial analysis of $U \& C D$ in operation, for example, the spatial reorganization of state power, or what Brenner refers to as state spatialisation strategies and the contradictions that flow from this. ${ }^{63}$ This lack of a spatial analysis is a major limitation of $U \& C D$, if we take heed of Henri Lefebvre's observation that 'the social relations of production have an existence to the extent they have a spatial existence; they project themselves into a space, becoming inscribed there, and in the process producing that space itself. ${ }^{64}$ The reorganisation of social relations implied by the term 'combination' must necessarily translate into a reorganisation of space. However, as noted, this is insufficiently explored through the extant literature on U\&CD. As Rosenberg himself has stated of U\&CD 'it lacks any tools for specifying the causal properties of those processes of social life to whose multiplicity and interaction it draws attention.' Consequently, 'it cannot operate as a replacement for the classical social theories whose limitations we are trying to overcome' and without these 'it cannot reach down

\footnotetext{
the Longue Durée (London; Roman and Littlefield International, 2016).

${ }^{58}$ Neil Smith, 'The Geography of Uneven Development', pp. 181-4.

${ }^{59}$ Van der Pijl, 'Uneven and Combined Development' pp.69-70.

${ }^{60}$ Rosenberg, 'Philosophical premises', pp.581-2.

${ }^{61}$ Rioux, Mind the (Theoretical) gap', p.484.

${ }^{62}$ Chris Hesketh and Adam D Morton, 'Spaces of Uneven Development and Class Struggle in Bolivia: Transformation or Trasformismo?', Antipode 46:1 (2014), pp.149-169.

${ }^{63}$ Neil Brenner, New State Spaces: Urban Governance and the Rescaling of Statehood (Oxford: Oxford University Press, 2009); see also Chris Hesketh, 'From passive revolution to silent revolution: Class forces and the production of state, space and scale in modern Mexico', Capital \& Class, 34:3 (2010), pp.383-407.

${ }^{64}$ Henri Lefebvre, The Production of Space, translated by Donald Nicholson-Smith (Oxford: Blackwell, 1990), p.129
} 
to the level of concrete historical explanation at all. ${ }^{65}$ Once again, when thought about in conjunction with passive revolution, this criticism can be overcome. It is to this concept that I now turn.

\section{Passive Revolution}

The concept of passive revolution was developed by Antonio Gramsci in his Prison Notebooks. ${ }^{66}$ It is intrinsically linked to the institutionalisation or expansion of capitalism (hence there is no possibility of its trans-historical extension). ${ }^{67}$ A passive revolution, or a 'revolution' without a "revolution", occurs when social relations are fundamentally reorganised (revolution) but ultimately, popular initiatives are neutralised so as to continue class domination (restoration). ${ }^{68}$ It therefore involves a combination of change and conservatism. 'The problem', argues Gramsci, 'is to see whether in this dialectic 'revolution/restoration whether it is revolution or restoration that predominates.' ${ }^{69}$ As Peter Thomas has pointed out, the concept of passive revolution was developed in multiple stages or 'cuts' within the Prison Notebooks as Gramsci began to appreciate the wider purchase that the term could have. ${ }^{70}$ Drawing from, but modifying Vincenzo Cuoco's initial use of the term, Gramsci first deployed passive revolution to refer to the role of the Piedmont state during the Italian Risorgimento and the limited form of hegemony that emerged from this. Key here is the role of the state in displacing social groups in leading a process of renewal. ${ }^{71}$ The term 'passive' was employed here to

\footnotetext{
${ }^{65}$ Callincos and Rosenberg, 'Uneven and combined development', p.86.

${ }^{66}$ We can trace precisely the chronology of how Gramsci developed his thought on this concept in the Prison Notebooks. Passive revolution is initially invoked by Gramsci when he refers to a 'revolution without revolution' in Q1§44 (written between 1929-30). The specific term passive revolution was added by Gramsci at a later date in the margins to this entry. In Q4§57 (written between 1930-32) Gramsci goes on to make reference to cases of passive revolution beyond Italy, where the same characteristic of modernising the state through reform, but without the same political revolution that France experienced, can be observed. The concept is developed further by drawing from Edgar Quinet's phrasing of 'revolution-restoration' in Q8§25 (1930-32) which is conjoined to Vincenzo Cuoco's term 'passive revolution' that Gramsci had appropriated. This notion of revolution-restoration as a process led from above is further expanded across Q10I\$9 (1932-33) to apply to the history of Europe following the French Revolution. In this same notebook and note, the significance of passive revolution for interpreting Fascism in Italy is discussed and the possibility of using the term to apply to broader European state formation linked to Americanism and Fordism is hinted at. The latter application of passive revolution is first suggestively written about in Q3\$11 (1930), but expanded far more in 1934 in Q22§1-15.

${ }^{67}$ Morton 'Continuum', p.319.

${ }^{68}$ Gramsci, Selections from the Prison Notebooks, p. 59, Q19§24, Bob Jessop, State Theory: Putting Capitalist States in their Place (Cambridge: Polity Press, 1990), p. 213.

${ }^{69}$ Gramsci, Selections from the Prison Notebooks,p.219, Q13\$27.

${ }^{70}$ Peter Thomas, 'Modernity as "passive revolution": Gramsci and the Fundamental Concepts of Historical Materialism', Journal of the Canadian Historical Association/Revue de la Société historique du Canada, 17:2 (2006), p.72.

${ }^{71}$ Gramsci, Selections from the Prison Notebooks, pp. 105-6, Q15§59.
} 
denote the difference between a national-popular movement from below, or what Gramsci calls 'a political revolution of a radical-Jacobin type' that overthrew the old feudal classes in France versus a revolution from above or 'royal conquest' that found accommodation with them in the case of Italy. ${ }^{72}$ Thus, rather than confronting and displacing the old feudal classes as occurred in France, the Risorgimento resulted in a compromised bourgeois transition. In Gramsci's words,

Restoration becomes the first policy whereby social struggles find sufficiently elastic frameworks to allow the bourgeoisie to gain power without dramatic upheavals, without the French machinery of terror. The old feudal classes are demoted from their dominant position to a 'governing' one, but are not eliminated, nor is there any attempt to liquidate them as an organic whole; instead of a class they become a 'caste' with specific cultural and psychological characteristics but no longer with predominant economic functions. ${ }^{73}$

Two wider issues require dwelling upon here. First, the Italian Risorgimento, theorised as a passive revolution, was clearly placed within the broader international context of uneven and combined development. As Gramsci states, 'It is also necessary to bear in mind that international relations become intertwined with those internal relations of a nation-state, and this, in turn, creates peculiar and historically concrete combinations. ${ }^{74}$ Capitalism was instituted therefore as a means of mimesis and (attempted) developmental catch up. ${ }^{75}$ To cite Gramsci once more, 'It was not so much a question of freeing the advanced economic forces from antiquated legal and political fetters but rather of creating the general conditions that would enable these economic forces to come into existence and grow on the model of other countries. ${ }^{76}$ Wider international factors were highlighted as vital to this, including foreign domination of the Italian peninsula, and in turn the influence of the French Revolution, not only in helping to ignite ideas of nationalism but later, with the sapping effect of the Napoleonic wars leading to a weakening of militant energy. ${ }^{77}$ However, international factors, although influential, were not seen as determinant with regards to the Risorgimento's outcome. Instead, the national peculiarities of Italy were also stressed as key factors in forging the sociopolitical consequences. Of particular note was the lack of major capital development in Italy, and,

\footnotetext{
72 Gramsci, Prison Notebbooks Vol.2, p. 232, Q4 §57; Antonio Gramsci, Prison Notebooks Vol.3 (ed. Joseph Buttigieg) (New York: Columbia University Press, 2011), p.60, Q6§78.

${ }^{73}$ Gramsci, Selections from the Prison Notebooks, p. 115, Q10II $\$ 61$.

${ }^{74}$ Gramsci, Prison Notebooks Vol.2 p.180, Q4§38, emphasis added.

${ }^{75}$ Adam D Morton, Unravelling Gramsci, p.63.

${ }^{76}$ Gramsci, Prison Notebooks Vol. 3, p. 60, Q6\$78 emphasis added.

${ }^{77}$ Gramsci, Selections from the Prison Notebooks, pp. 84-5, Q19\$28.
} 
unlike the French situation, no organic link between urban and rural areas. Instead, there remained an important divide between the urban North and the rural South that, far from being overcome, was in fact perpetuated with unification, with a parasitic industrial North exploiting the agrarian South. ${ }^{78}$ Gramsci concluded that the revolutionary leaders in Italy were 'aiming at the creation of a modern state but in fact produced a bastard. ${ }^{79}$ This was owing to the new state's limited hegemonic base, founded as it was on a compromise between the old aristocracy and the emerging industrialists. Lacking national-popular appeal, these classes only achieved a weak hegemony over the rest of society and therefore had a poor capacity to economically transform the country. ${ }^{80} \mathrm{We}$ can witness here how the concept itself (as with all of Gramsci's concepts), was developed through historical and geographical specificity. ${ }^{81}$ To return to Halliday's key points about what the study of revolution should entail in IR, we can see that passive revolution is clearly able to locate the place of revolutions and discuss their importance for the international system more broadly. We can also conclude from the above example that 'the notion of passive revolution is able to encapsulate specific processes within the general circumstances of uneven and combined development. ${ }^{82}$ It therefore covers Halliday's second criteria by exploring the international dimensions of any revolution. Moreover, in being able to move through varying spatial scales (down to the level of the subnational in the discussion of the role of Piedmont), it is precisely able to reach down to the level of concrete historical explanation that Rosenberg has admitted U\&CD cannot do. What then of Halliday's third category of theoretical reflection?

Gramsci quickly came to realise that the term had far greater purchase as an analytical category beyond the scope of Italian history. The second usage of passive revolution then came from processes

\footnotetext{
${ }^{78}$ Antonio Gramsci, 'Some aspects of the southern question' in Selections from Political Writings (1921-1926), translated and edited by Quentin Hoare, (London: Lawrence and Wishart, 1978); Gramsci, Prison Notebooks Vol.1, p.143, Q1§44.

${ }^{79}$ Gramsci, Selections from the Prison Notebooks, p. 90, Q19§28.

${ }^{80}$ Sassoon, Gramsci’s Politics, p.207.

${ }^{81}$ Bob Jessop, 'Gramsci as a Spatial Theorist', Critical Review of International Social and Political Philosophy, 8:4 (2005), pp.421-437; Stefan Kipfer 'City, Country, Hegemony: Antonio Gramsci’s Spatial Historicism' in Michael Ekers, Gillian Hart, Stefan Kipfer and Alex Loftus (eds), Gramsci Space, Nature, Politics (Oxford: Wiley Blackwell, 2013), pp. p. 85.

${ }^{82}$ Morton, 'Waiting for Gramsci', p. 612.
} 
of state formation in Europe that had undergone a similar process to Italy, namely in trying to achieve developmental catch up and thereby transforming social relations, but without significant input from below. Rather these were 'revolutions from above' that sought to remake society. ${ }^{83}$ Bismark's Germany would be a classic example of this, ${ }^{84}$ but, as will be discussed in the next section, European development in general post-French Revolution was seen as the history of passive revolution. ${ }^{85}$ As Bruff surveys, the concept of passive revolution was, from its genesis, expansionary in nature, linked to the need to situate Italian development in the broader international context and second to analyse the contemporaneous transformations in other European societies. ${ }^{86}$ It is the latter that then provide the basis for thinking about the diverse geographical seats.

Finally, in his discussion of Americanism and Fordism, Gramsci discusses how passive revolution can be used as a broader category of analysis and interpretation. ${ }^{87}$ Here it refers to a generalised means of statecraft in the expansion of capitalism but with pacifying reforms (which are themselves a response to subaltern class pressures). As Peter Thomas has argued, in this final usage, passive revolution refers less to a specific event but rather to a more generalised process or logic of modernisation. ${ }^{88}$ In sum, therefore, passive revolution is about the reorganisation and restoration of class power. This involves a process of transformism whereby there is 'the formation of an ever more extensive ruling class within an already established framework. ${ }^{89}$ It includes elements of both revolution (in transforming the social relations of production) and restoration (maintenance/ continuity of power structures without significant subaltern empowerment). Finally, its central feature is statisation, with the state replacing social groups in leading the process of renewal. ${ }^{90}$ In all the instances in which it is invoked, passive revolutionary forms of state formation are tied to key events that serve as punctual moments of history.

\footnotetext{
${ }^{83}$ Gramsci, Prison Notebooks Vol. 2, p. 232, Q4 §57.

${ }^{84}$ Thomas, 'Modernity as "passive revolution', p.72.

${ }^{85}$ Gramsci, Selections from the Prison Notebooks, pp.118-120, Q10I§9.

${ }^{86}$ Ian Bruff, 'Germany's Agenda 2010 reforms: Passive revolution at the crossroads', Capital \& Class, 34:3 (2010b), pp.411

${ }^{87}$ Gramsci, Selections from the Prison Notebooks, pp. 277- 318, Q22§1-15.

${ }^{88}$ Thomas, 'Modernity as "passive revolution', p. 73.

${ }^{89}$ Gramsci, Selections from the Prison Notebooks, p.58, Q $19 \S 24$.

${ }^{90}$ Gramsci, Selections from the Prison Notebooks, pp.106-8, Q15§59, 17.
} 
What then is the case for thinking about its universal applicability? Gramsci himself noted that, 'since similar situations almost always arise in every historical development, one should see if it is not possible to draw from this some general principle of political science and art. ${ }^{, 91} \mathrm{He}$ also queried in his day whether passive revolution would have an enduring relevance, asking 'Does the conception of the "passive revolution" have a "present" significance? Are we in a period of "restoration revolution" to be permanently consolidated, to be organised ideologically, to be exalted lyrically?'.92 As Adam Morton has previously elucidated, to explore this issue requires that we do not simply apply Gramsci's concepts mechanically to other historical eras and places, but rather we are required to think in a Gramscian way, asking, most importantly, whether 'theory can advance a practical understanding of a concrete reality or situation that is different from that in which it originated'. ${ }^{93}$ However, in this effort to find commonality and interpretative resonance we must be fully aware of the dangers of the not letting over-generalised claims lose their critical purchase. ${ }^{94}$ It is here that I believe the strict geographical rendering of passive revolution becomes relevant and this will be returned to towards the end of the following section and in the concluding discussion.

\section{The case for passive revolution's universal applicability}

Stefan Kipfer has noted that Gramsci was 'particularly interested in conjunctures: historical moments that articulate the punctual temporality of the event with longer-term forms of historical duration. ${ }^{95}$ This is especially important when analysing how Gramsci came to develop the term passive revolution, from the Italian Risorgimento onwards. The key punctual moment for Gramsci was the experience of the French Revolution (1789-1799) and its aftermath. This not only made the Italian Risorgimento comparable in terms of the distinct lack of a national-popular hegemonic project articulated in Italy as compared to France, but also allowed Gramsci to see the history of nineteenthcentury Europe as a series of passive revolutions, or what he saw as reforms from above (owing to the

\footnotetext{
${ }^{91}$ Gramsci, Selections from the Prison Notebooks, pp.108-9, Q15§11.

${ }^{92}$ Gramsci, Selections from the Prison Notebooks, p. 118, Q10I§9).

${ }^{93}$ Morton, Unravelling Gramsci, pp.18, 34.

${ }^{94}$ Morton, 'Contiuum' p.330.

${ }^{95}$ Kipfer, “'City, Country, Hegemony', p.86.
} 
cumulative process of history). This was achieved by 'successive waves of small reform rather than revolutionary explosions' (which nevertheless took on local characteristics), and were designed precisely to offset the more dramatic upheavals of the French case. ${ }^{96}$ Here the conditioning situation of uneven and combined development was clearly noted. The example of revolutionary transformation could not be contained within isolated borders and stimulated a class-based reaction to it from other European countries which in turn fostered the Napoleonic Wars. ${ }^{97}$ However, a longerterm pattern of nationalism and reformism were to be the geographically specific reactions to this event, internalised within state forms so as to modernise on the continued premise of class domination.

Beginning in the 1930s but consolidating further with the end of the Second World War (beyond the lifetime therefore of Gramsci who died in 1937), Americanism and Fordism was identified as another era that ushered in a new wave of passive revolution. Lurking here was of course the threat of communism and the Bolshevik example, propelling governments to take reformist steps to absorb working class radicalism through limited means of wealth redistribution. ${ }^{98}$ The Russian Revolution of 1917 therefore served as another key punctual moment of history. For most of the Western World, this new epoch of passive revolution was experienced as a relatively progressive, albeit contradictory, form development (exemplified by Keynesianism). This served to statise discontent, expanding capitalism whilst offering real but limited concessions to the subaltern classes. It thereby displaced more radical demands whilst not offering meaningful political inclusion or economic justice (key hallmarks of passive revolution). It should be noted that Gramsci's analysis of Fordism was prescient, arguing that the benefits of high wages were likely to be transitory and could only be secured so far as they corresponded to the early monopoly phase of capitalism. ${ }^{99} \mathrm{He}$ (correctly) predicted that they

\footnotetext{
${ }_{97}^{96}$ Gramsci, Selections from the Prison Notebooks, p.115, Q10II§61.

${ }^{97}$ Theda Skocpol and Meyer Kestenbaum, 'Mars Unshackled: The French Revolution in World-Historical Perspective', in Ferenc Fehér (ed.), The French Revolution and the Birth of Modernity, Berkeley: University of California Press, 1990).

${ }_{98}$ Christopher Chase-Dunn, 'Globalization: A world-systems perspective', Journal of World-Systems Research, 5:2(1999), p. 204.

${ }^{99}$ Gramsci, Selections from the Prison Notebooks, p. 311, Q22§13.
} 
would soon be eroded via competition, which of course was to be a contributing factor to Fordism's eventual demise and replacement with a neoliberal model, itself a further punctual moment in history.

Finally, it is worth noting that fascism in Italy was viewed by Gramsci as an alternative trajectory of passive revolution based on the same logic; namely, a defensive ruling class stratagem of developmental catch up that sought to augment their own dominant position whilst transforming social relations in line with the competitive pressures emanating from the international political economy. Fascism was therefore interpreted by Gramsci as being analogous (and connected) to the moderate and conservative regimes of the previous century in the sense of seeking to preserve the political and economic position of the old feudal classes by avoiding major agrarian reform. ${ }^{100}$ Moreover, Italian Fascism was interpreted as a form of revolution from above that, whilst changing productive relations, did not offer significant empowerment for the subaltern classes. As Gramsci clarifies,

relatively far-reaching modification are being introduced into the country's economic structure in order to accentuate the 'plan of production' element; in other words, that socialisation and co-operation in the sphere of production are being increased, without however touching (or at least not going beyond the regulation and control of) individual and group appropriation of profit. ${ }^{101}$

This was linked to the need of Italy to compete with more advanced nations who not only had larger stores of raw materials resulting from their colonial possessions, but also had higher levels of capital owing to their earlier transitions from feudalism.

Beyond the specific cases provided by Gramsci, there are further examples that can be utilised to build the case for the universal experience of passive revolution (moving away from simply a phenomenon concerned with the West). An important category to include here is the wave of nationalist movements that occurred in the wake of decolonisation after 1945 . These took place beyond the lifetime of Gramsci, but it is nevertheless revealing that he refers to Gandhi as having a

\footnotetext{
${ }^{100}$ Gramsci, Selections from the Prison Notebooks, p.119, Q10I§9.

${ }^{101}$ Gramsci, Selections from the Prison Notebooks, p. 120, Q10I§9.
} 
naïve theoristisation of passive revolution. ${ }^{102}$ Partha Chatterjee has gone so far as to claim that 'passive revolution is the general form of the transition from colonial to the post-colonial nationalstates of the 20th century', whilst Morton has described passive revolution as a hallmark of postcolonial capitalism. ${ }^{103}$ In his specific analysis of India, Chatterjee refers to the nationalist movement as moving through three phases. First, there is the 'moment of departure' where struggle and rebellion open space for a new political project. This emphasises the strength of Western material conditions and progress but nevertheless claims a superior Eastern cultural quality. Second, there is the 'moment of manoeuvre'. This involves the emergence of new elites in national alliance who seek to mobilise subaltern classes in an anti-colonial struggle, yet sustain the belief that only educated elites can provide the necessary cultural synthesis of East and West needed for developmental catch up. Subaltern elements are therefore distanced from the structures of the state. Finally, there is the 'moment of arrival' leading to exclusion, repression and the marginalisation of subaltern elements. Radical rupture becomes de-emphasised as a discourse of order is established. ${ }^{104}$ Such an analysis has been utilised elsewhere to explain further forms of peripheral state formation. ${ }^{105}$ The import here is to not only recognise the structural conditioning of the international system (as per U\&CD) but to then focus our attention on the precise modalities of class forces constructing a national project. As Morton has argued, this enables us to construct an 'interpretive method in historical sociology focusing on inter-related instances of state transition within world-historical processes, where the particulars of state formation are realised within the general features of capitalist modernity'. ${ }^{106}$ To phase this another way, the universal pressures generated from capitalist geopolitical competition are acknowledged but the geographical seats of class articulation remain the priority for analysis.

\footnotetext{
${ }^{102}$ Gramsci, Selections from the Prison Notebooks, p.107, Q15§17.

${ }^{103}$ Partha Chatterjee, Nationalist thought and the colonial world: A derivative discourse (London: Zed Books, 1986), p. 50; Morton, Revolution and the State, p. 243

${ }^{104}$ Chatterjee, Nationalist Thought, p. 51.

${ }^{105}$ Florencia Mallon, Peasant and Nation: The Making of Postcolonial Mexico and Peru (Berkeley: University of California Press, 1995).

${ }^{106}$ Morton, Continuum', p.332.
} 
A final example to be invoked in order to demonstrate the universal applicability of passive revolution is the case of Latin American state formation in the twentieth century. ${ }^{107}$ Robert Cox has noted that passive revolution and the associated notion of transformism are especially apposite concepts for developing regions. ${ }^{108}$ Although this has already been established to a degree with regards to postcolonial societies in general, it is worth exploring the Latin American case specifically as formal independence in the continent had been achieved much earlier here, yet patterns of neo-colonial domination remained crucial influences. ${ }^{109}$ It has been widely recognised that Latin American state formation in the twentieth century was one that was clearly marked by the structural condition of 'delayed dependent development'. ${ }^{110}$ Resulting from this was the need to engage in developmental catch up so as to avoid stagnation or subordination. This was most clearly manifested, first through import-substitution industrialization (ISI) and the associated populist political project, and secondarily with the turn to authoritarianism (which itself emerged from the contradictions of the previous strategy).

The international context of uneven and combined development was clearly vital for fostering the turn to ISI in Latin America in terms of the Great Depression and World War II. This cut the region off from previous markets and forced the continent, by necessity, towards greater internal production of goods. Furthermore, the changing character of hegemony at the international level from the Pax Britanica to the Pax Americana was also important (providing a changing centre of irradiation). Linked to previous discussions, American hegemony after World War II would presage the rise of worldwide industrial productive relations linked to Fordism which entailed a much stronger role for state intervention in managing the economy. ${ }^{111}$ These emerging economic ideas would be used to

\footnotetext{
${ }^{107}$ See also Ronaldo Munck, Rethinking Latin America: Development, Hegemony, and Social Transformation (Palgrave Macmillan, 2013).

${ }^{108}$ Robert Cox, 'Gramsci, Hegemony and International Relations', p.167.

${ }^{109}$ Henrique Cardoso and Enzo Faletto, Dependency and Development in Latin America, trans. Marjory M. Uruidi (Berkeley: University of California Press, 1979).

${ }^{110}$ James Malloy 'Authoritarianism and Corporatism in Latin America: The Modal Pattern', in James Malloy (ed), Authoritarianism and corporatism in Latin America (London: University of Pittsburgh Press, 1977), pp.319.

${ }^{111}$ Andrew Glyn, Alan Hughes, Alain Lipietz and Ajit Singh, 'The Rise and Fall of the Golden Age' in Stephen Marglin and Juliet Schor (eds), The Golden Age of Capitalism: Reinterpreting the Postwar Experience (Oxford: Clarendon Press, 2000), p.56.
} 
enhance the power of nascent elites in Latin America and provide an atmosphere convivial to their further expansion despite their small number. Gramsci was attentive to the manner in which geographical interlinkages such as these were integral to passive revolutionary processes, highlighting how, in many cases: 'the impetus of progress is not tightly linked to a vast local economic development...but is instead the reflection of international developments which transmit their ideological currents to the periphery - currents born of the productive development of the advanced countries. ${ }^{112}$ In other words, the changing character of hegemony in the international political economy laid the foundations that were conducive for change in the character of hegemony at other spatial scales such as the regional and the national levels. This is not to say that the outcome of social struggle over the state form was pre-determined by the international sphere, merely that the terrain was created in which certain modes of development could be more favourably articulated. The social compromise that was ISI can be seen as a response to 'activated' subaltern classes but one in which these subaltern classes did not fully come to author the process themselves. ${ }^{113}$ Rather, populism combined nationalism with developmentalism in its rejection of the previous liberal, oligarchic model. However, populism was statist as opposed to socialist. Reformist, not revolutionary, and as a political project it appealed to the idea of social harmony rather than stressing class differences (for which appeals to nationalism helped provide the mediating ideology). Once again we can witness the role of the state in leading the process of change and mollifying more radical demands. The shift to authoritarianism in Latin America in the 1960s and 1970s (largely in the southern cone) demonstrates well the example of further punctual moments of history spilling over into a regional setting. If it is impossible to write a history of Europe without the French Revolution, then it is equally impossible to write a history of Latin America without the Cuban Revolution. As Jorge Castañeda has noted, Cuba was the crucible of revolutionary activity for Latin America. ${ }^{114}$ The failure of populism to achieve its stated aims of developmental catch up, combined with fears of the Cuban example spreading through the continent, led many states to forge an alliance with international capital and the domestic

\footnotetext{
${ }^{112}$ Gramsci, Selections from the Prison Notebooks, p. 116-117, Q10II§61 emphasis added.

${ }^{113}$ Guillermo O'Donnell, 'Corporatism and the Question of the State' in James Malloy (ed) Authoritarianism and Corporatism, pp.44-87; Munck, Rethinking Latin America, p.87.

114 Jorge Castañeda, Utopia Unarmed: The Latin American Left After the Cold War, (New York: Vintage Books, 1993), pp.51-89.
} 
bourgeoisie to further expand capital accumulation. ${ }^{115}$ This led to a new intensified pressure to achieve rapid social change from above, without subaltern class participation. In effect the state had moved from a process of controlled inclusion to one of coerced marginalisation. ${ }^{116}$

If the above examples paint in broad brush stroke about its universal applicability to different regions, a survey of recent literature (that is illustrative rather than exhaustive) reveals that the concept has indeed had purchase on a variety of historical and contemporary processes of state formation and in various contexts demonstrating the richness of its theoretical import on the ground (its geographical seats). Within Latin America passive revolution has been used to analyse the Mexican Revolution as well as the period of neoliberal restructuring following the 1982 debt-crisis. ${ }^{117}$ It has been applied to an understanding of Bolivian state formation since the Revolution of 1952, including that of the current Evo Morales administration. ${ }^{118}$ Marcos del Roio has sought to 'translate' passive revolution into the Brazilian context whilst Phillip Roberts has used the concept to explore the changing role of religion in Brazil's development. ${ }^{119}$ Passive revolution has also been invoked to analyse the role of the Chilean Socialist Party (as part of the Concertación) in helping to construct neoliberalism in the postauthoritarian era. ${ }^{120}$ Finally, Massimo Modonesi has used the concept to analyse the role left-of-centre governments associated with the Pink Tide phenomenon more generally in the region. ${ }^{121}$ In the European context, passive revolution has been used to explain the post-communist transition in in

\footnotetext{
${ }^{115}$ O’Donnell, 'Corporatism', p. 62.

116 Phillip Oxhorn, 'From Controlled Inclusion to Coerced Marginalization' in John Hall (ed), Civil Society: Theory, History, Comparison (Cambridge: Polity Press, 1995).

117 Hesketh, 'From Passive Revolution' Adam D Morton 'Structural Change and neoliberalism in Mexico: 'passive revolution' in the global political economy', Third World Quarterly, 24:4 (2003), pp.631-653.

Morton, 'Reflections on Uneven Development'; Morton, Revolution and the State.

${ }^{118}$ Hesketh and Morton, 'Spaces of Uneven Development'; Luis Tapia, El Estado de Derecho como Tiranía (La Paz: CIDES/UMSA, 2011).

119 Marcos del Roio, 'Translating passive revolution in Brazil', Capital \& Class, 36:2 (2012), pp.215-234; Phillip Roberts, 'Passive revolution in Brazil: struggles over hegemony, religion and development 1964-2007', Third World Quarterly, 36:9 (2015), pp.1663-1681.

${ }^{120}$ Sara Motta, 'The Chilean Socialist Party (PSCh): Constructing consent and disarticulating dissent to neoliberal hegemony in Chile', The British Journal of Politics and International Relations 10: 2 (2008), pp. 303327.

${ }^{121}$ Massimo Modonesi, 'Revoluciones pasivas en América Latina: una aproximación gramsciana a la caracterización de los gobiernos progresistas de inicio de siglo'. In M Modonesi (ed) Horizontes Gramscianos: Estudios en torno al pensamiento de Antonio Gramsci (México DF: UNAM, 2013).
} 
Eastern Europe and the increasing role of transnational capital, ${ }^{122}$ and more recently the rise of the Justice and Development party in Turkey, headed by Recep Tayyip Erdoğan. ${ }^{123}$ In South-East Asia, Japan's Meiji restoration has been viewed through the lens of passive revolution as have contemporary Chinese labour struggles. ${ }^{124}$ Finally, with regards to Africa, at a regional level, the general trend of democratisation in sub-Saharan Africa has been interpreted as a passive revolution as have the specific cases of state formation in South Africa under the African National Congress (ANC) and most recently Malawi. ${ }^{125}$

These separate analyses speak for themselves in showing the diverse applicability of passive revolution (and as such should be read for their own merits). What can be discerned here is an affirmative answer as to whether the concept has purchase in explaining concrete situations beyond its initial historical formulation (as Gramsci predicted). It is, however, instructive to note that when initially developed by Gramsci, passive revolution was used to describe the origins of European capitalism as well as its intensification following the rise of Fordism. In recent years, however, it has undoubtedly gained more purchase as a mode of analysing peripheral capitalist spaces (as the above examples indicate). Instead, European state formation post the 2008 financial crisis has been analysed in terms of the shift towards 'authoritarian neoliberalism', as a response to the crisis of legitimacy of capitalist states. ${ }^{126}$ An open question will be whether the longer-term response to this crisis, which has

\footnotetext{
${ }^{122}$ Dorothee Bohle, 'Neoliberal hegemony, transnational capital and the terms of the EU's eastward expansion', Capital \& Class 30:1 (2006), pp. 57-86; Stuart Shields, 'Historicizing Transition: The Polish Political Economy in a Period of Global Structural Change-Eastern Central Europe's Passive Revolution?', International Politics 43:4 (2006), pp.474-499; Rick Simon, 'Passive revolution, perestroika, and the emergence of the new Russia', Capital \& Class 34:3 (2010), pp. 429-448.

123 Cihan Tugal, Passive revolution: Absorbing the Islamic challenge to capitalism (Stanford: Stanford University Press, 2009).

${ }^{124}$ Jamie Allinson and Alexander Anievas, 'The uneven and combined development of the Meiji Restoration: a passive revolutionary road to capitalist modernity', Capital \& Class, 34:3 (2010), pp. 469-490; Kevin Gray, 'Labour and the state in China's passive revolution', Capital \& Class, 34:3 (2010), pp. 449-467.

${ }^{125}$ Rita Abrahamsen, 'The victory of popular forces or passive revolution? A neo-Gramscian perspective on democratisation', Journal of Modern African Studies, 35:1(1997), pp.129-152; Gillian Hart, Rethinking the South African Crisis: Nationalism, Populism, Hegemony (London: University of Georgia Press, 2014); Fiona Nash, 'Participation and passive revolution: the reproduction of neoliberal water governance mechanisms in Durban, South Africa', Antipode, 45:1 (2015), pp.101-120; Andrew Brooks and Alex Loftus, 'Africa's passive revolution: crisis in Malawi', Transactions of the Institute of British Geographers, 41:3 (2016), pp.258-272.

${ }^{126}$ Ian Bruff, 'The Rise of Authoritarian Neoliberalism', Rethinking Marxism, 26:1 (2014), pp.113-129
} 
seen the so-called 'return of the state', ${ }^{127}$ will augur a new wave of passive revolution within the capitalist heartlands or whether the potential exists for a genuine subaltern hegemonic project. As Gramsci wisely indicated with regards to this, crises do not in and of themselves determine historical situations, rather they provide the terrain on which such struggles occur. ${ }^{128}$

\section{Conclusion}

Given the way in which passive revolution has been inextricably tied to the broader notion of uneven and combined development, what then does this concept add that is not already present within the former notion? In looking at the value of conjoining passive revolution to U\&CD I believe three issues stand out, all of which are in some manner inter-related.

First, the usage of passive revolution can overcome the criticism of U\&CD as being aspatial. Rather than setting up a broad trans-historical method of abstract inquiry, passive revolution forces us to explore specific cases (the geographical seats) within the framework. Passive revolution becomes the political method of analysis where uneven development results in combination within a broader capitalist global political economy. The very nature of the concept invites us to examine the peculiarities of national state formation linked to developments within the broader international context in a similar manner to U\&CD itself. However, the originality here comes from the fact that passive revolution also enables us to explore the further ongoing consequences of uneven development that result from such a process, linked to the construction of hegemonic projects of new class alliances. The construction of state formation across multiple spatial scales is thereby revealed through this method. ${ }^{129}$ This was integral to Gramsci's method and it is precisely what allowed him to see Fascism as the result of the unresolved class antagonisms embodied in the Italian Risorgimento. ${ }^{130}$ Concurrent with Morton, 'Beyond an initial ruptural feature of modern state formation, a passive

\footnotetext{
${ }^{127}$ John Plender, 'The Return of the State: how government is back at the heart of economic life', Financial Times (21 August 2008).

${ }^{128}$ Gramsci, Selections from the Prison Notebooks, p. 184

129 Chris Hesketh, 'Producing State Space in Chiapas: Passive Revolution and Everyday Life' Critical Sociology, 42:2, (2016), pp. 211-228.

${ }^{130}$ Gramsci, Selections from the Prison Notebooks, pp67-68, Q19§24, 119-120, Q10I§9; see also Hesketh and Morton, 'Spaces of Uneven Development', for a discussion of Bolivia along a similar line.
} 
revolution has ongoing effects that subsequently shape the contingent and structural conditions of uneven and combined capitalist development.' ${ }^{131}$

Second, with passive revolution there is a focus on class agency as opposed to only looking at the structural conditioning situation, something U\&CD slides into quite easily. ${ }^{132}$ To misquote Eric Wolf, the type of grand narrative offered by U\&CD can unfortunately translate into a story about 'the international' and the people without history. ${ }^{133}$ By contrast, passive revolution reverses this formulation. As Peter Thomas rightly claims, passive revolution 'analyses the formation of determining structures through the activity of the determinate social actors. ${ }^{134}$ It reveals the political strategies of the state, therefore, in authoring such forms of class transition. However, this is not simply a narrative of despair and resigned fatalism that speaks to a timeless element of the human condition. As Gramsci reminds us "'the conception remains a dialectical one - in other words, presupposes, indeed postulates as necessary, a vigorous anti-thesis which can present intransigently all its potentialities for development. ${ }^{135}$ In declaring that passive revolution is a universal concept we also need to explore the other side of this coin which is the active revolution or anti-passive revolutionary tactics of subaltern struggles. ${ }^{136}$

This leads to the final advantage of deploying the term passive revolution - namely that it is more instantly politicised than U\&CD. As noted above, it is concerned first and foremost with the institutionalisation or expansion of capitalism. This means that it necessarily relates to recent history and the immediate present as engaged critique (as opposed to a trans-historical social theory with largely academic value). Passive revolution draws our attention to the state form as an object of criticism and thus can aid our understanding of political struggle, not so much in providing an answer to Lenin's famous question of 'What is to be done?' but rather in offering a strategic orientation as to

\footnotetext{
${ }^{131}$ Morton, Revolution and the State, p. 239, emphasis added.

${ }^{132}$ Van der Pijl, Uneven and Combined Development', p. 72.

${ }^{133}$ Wolf, Europe and the People.

134 Thomas, 'Modernity as “passive revolution', p. 75.

${ }^{135}$ Gramsci, Selections from the Prison Notebooks, p. 114, Q15\$62.

${ }^{136}$ Morton, Unravelling Gramsci, p. 191, 197; Sassoon, Gramsci's Politics, p.216
} 
what is to be avoided. As well as an interpretation of history, passive revolution is also a warning from history, and forewarned is forearmed. Against a so-called passive revolution, what is needed is an anti-passive revolution or an active revolution. Stephen Gill has argued that the concepts passive revolution and hegemony should be thought of as 'end-points in a continuum of actual historical (and indeed possible) transformations. ${ }^{, 137}$ Passive revolution therefore refers less to the strength of a dominant class, but rather the weakness of their adversaries in forming alternatives. ${ }^{138}$ The construction of subaltern hegemony is therefore an imperative task. However, the challenge of how to do this needs to be informed by the logic of passive revolution. This requires that to go back to the fundamental Marxist critique of the state as a special type of organisation that is super-imposed upon society rather than subordinate to it. ${ }^{139}$ What one must examine therefore is whether social struggles are reconstituting society as society or in fact reconstituting the power relations of the state. ${ }^{140}$ The words of Henri Lefebvre are prescient here. Although he never used the specific term passive revolution, he nevertheless usefully points to the dangers of it, warning social movements of "the triple trap of substitution (of authority for grassroots action), transfer (of responsibility from activists to the 'leaders') and displacement (of the objectives and the stakes of social protest to the goals set by the 'bosses' who are attached to the established order.' 141

Where does this leave social movements and those wishing to affect change? As suggested earlier in the article, one crucial element is to make the concept of passive revolution an element of culture, beyond professional intellectuals. Beyond this we may also think about coming full circle to the relationship between Trotsky and Gramsci. Whereas the article started with Trotsky and U\&CD, before moving on to discuss Gramsci and the manner in which passive revolution complements this

\footnotetext{
${ }^{137}$ Stephen Gill, Power and Resistance in the New World Order 2nd edition. (Basinstoke: Palgrave, 2008), p. 58 .

${ }^{138}$ Sassoon, Gramsci’s Politics, p. 204).

${ }^{139}$ Karl Marx, 'Critique of the Gotha Programme' in David McLellan (ed) Karl Marx: selected writings $2^{\text {nd }}$ edition (Oxford: Oxford University Press, 2000); Vladamir Ilyich Lenin, 'The State and Revolution', in Henry M. Christman (ed), Essential Works of Lenin (New York: Dover Publications 1987), p.301.

${ }^{140}$ Henri Lefebvre, The Survival of Capitalism: Reproduction of the Relations of Production, trans. Frank Bryant) (London: Allison and Busby, 1976), p.125.

${ }^{141}$ Henri Lefebvre 'Space and State'. in Neil Brenner, Bob Jessop, Martin Jones and Gordon Macloed, (eds), State/Space: A Reader (Oxford: Blackwell, 2003), p. 96, emphases added.
} 
theoretical notion to analyse capitalist modernity. I would now suggest that if we are to put an end to passive revolution as a universal characteristic of modernity then it requires that its antithesis be developed to the maximum possibility. An active revolution that reaches beyond borders must be based in something akin to what Trotsky called a 'permanent revolution'. The modalities of how such a permanent revolution could and should be enacted remain, of course, another discussion entirely.

\section{Acknowledgements}

I am grateful to Adam Morton and Cemal Burak Tansel for their comments on an earlier draft of this article as well as the comments from two anonymous referees. 